\title{
MENINGKATKAN KEMAMPUAN BERPIKIR KRITIS MATEMATIS DAN KEPERCAYAAN DIRI SISWA SMP MELALUI PENDEKATAN OPEN ENDED
}

\author{
Chandra Novtiar ${ }^{1}$, Usman Aripin ${ }^{2}$ \\ ${ }^{1}$ Program Studi Pendidikan Matematika, IKIP Siliwangi \\ chandramathitb07@gmail.com \\ ${ }^{2}$ Program Studi Pendidikan Matematika, IKIP Siliwangi \\ usmanaripin@gmail.com
}

\begin{abstract}
ABSTRAK
Penelitian ini dilatarbelakangi oleh rendahnya kemampuan berpikir kritis matematis dan kepercayaan diri siswa SMP. Untuk mengatasi permasalahan tersebut diperlukan salah satu pendekatan pembelajaran yang diharapkan mampu mengembangkan kemampuan berpikir kritis matematis dan kepercayaan diri siswa adalah pendekatan open ended. Melalui pembelajaran ini, siswa terlibat langsung dan belajar mengeluarkan ide-ide dalam menyelesaikan soal-soal bersifat open ended, sehingga membangkitkan minat siswa untuk aktif selama proses pembelajaran. Diharapkan melalui pembelajaran ini, siswa menjadi termotivasi, ulet dan bersungguh-sungguh dalam memahami matematika sehingga dapat meningkatkan kepercayaan diri siswa. Bentuk luaran dari penelitian ini berupa produk bahan ajar bersifat open ended yang dapat dimanfaatkan oleh guru dalam pembelajaran. Metode penelitian yang digunakan adalah quasi experimental dengan bentuk desain Nonequivalent Control Group Design, dimana subyek penelitian tidak dikelompokkan secara acak. Populasi dalam penelitian ini adalah siswa SMP kota Cimahi, sedangkan sampelnya SMP Taruna Mandiri kemudian diambil dua kelas secara acak kelas, diperoleh kelas 7B sebagai kelas eksperimen dan kelas 7C sebagai kelas kontrol. Pengumpulan data dalam penelitian ini berupa tes sebanyak 5 soal uraian kemampuan berpikir Kritis dan 20 butir soal skala sikap kepercayaan diri dalam belajar matematika, kemudian data tersebut dianalisis dengan statistik deskriptif dan inferensial dengan menggunakan uji perbedaan dua rata-rata. Berdasarkan hasil penelitian, baik dari hasil analisis data maupun pengujian hipotesis, maka penulis menyimpulkan bahwa peningkatan kemampuan berpikir kritis dan pencapaian kepercayaan diri dalam belajar matematik siswa yang pembelajarannya menggunakan pendekatan open-ended lebih baik daripada pendekatan konvensional.
\end{abstract}

Kata kunci: Kemampuan Berpikir Kritis matematis, Kepercayaan Diri, Pendekatan Open Ended

\section{PENDAHULUAN}

Matematika merupakan salah satu ilmu yang mengandalkan proses berpikir. Dalam proses pembelajarannya matematika merupakan salah satu matapelajaran yang sangat penting untuk dipelajari karena hampir disetiap jenjang pendidikan matematika dipelajari. Hal ini bisa terjadi karena matematika merupakan aktivitas kehidupan manusia artinya setiap aktifitas 
manusia pasti menggunakan ilmu matematika, mulai dari ibu rumah tangga, pedagang, pelajar dll semua pekerjaan melakukan aktivitas matematika sesuai dengan kebutuhannya. Selain itu matematika juga mengajarkan pola berpikir kritis, analitis dan sistematis dalam pemecahan masalah baik pada pelajaran matematika atau dalam kehidupannya.

Kemampuan berpikir kritis merupakan salah satu salah satu kemampuan berpikir tingkat tinggi. Sumakim (Jumaisyaroh, 2014) mengatakan bahwa keterampilan berpikir kritis matematis sangat penting bagi siswa karena dengan keterampilan ini siswa mampu bersikap rasional dan memilih alternatif pilihan yang terbaik bagi dirinya. Selain itu, menanamkan kebiasaan berpikir kritis matematis bagi pelajar perlu dilakukan agar mereka dapat mencermati berbagai persoalan yang terjadi dalam kehidupan sehari-hari.

Mengajarkan kemampuan berpikir kritis matematis kepada siswa diharapkan siswa mampu mengembangkan pola berpikir agar generasi muda di masa yang akan datang mampu bersaing di tingkat global. Namun pada kenyataannya, menurut Syahbana (2012), kebiasan berpikir kritis ini belum ditradisikan di sekolah-sekolah. Seperti yang diungkapkan kritikus Jacqueline dan Brooks (Syahbana, 2012), sedikit sekolah yang mengajarkan siswanya berpikir kritis. Sekolah justru mendorong siswa memberi jawaban yang benar daripada mendorong mereka memunculkan ide-ide baru atau memikirkan ulang kesimpulan-kesimpulan yang sudah ada.

Menurut studi pendahuluan yang telah fauziyah (2016) lakukan, siswa di era modern ini dinilai 'kurang berpikir'. Beberapa siswa pergi dari rumah ke sekolahnya hanya untuk belajar mendengarkan dan mencatat apa yang dikatakan guru, kemudian mengerjakan beberapa soal yang dicontohkan oleh gurunya. Sejauh ini kebanyakan dari mereka hanya menghafal teori atau rumus yang diberikan oleh guru.

Berdasarkan hasil penelitian Syahbana (2012) menunjukkan bahwa masih rendahnya rata-rata kemampuan berpikir kritis matematis siswa SMP. Nilai rata-rata kemampuan berpikir kritis matematis siswa SMP hanya 68 kalau dalam skala 0-100, nilai ini baru termasuk dalam kategori cukup. Selain itu, dari penelitian awal dengan memberikan tes kemampuan berpikir kritis matematis yang dilakukan oleh peneliti di SMP Ar-rahman Percut, dari 30 siswa hanya 2 orang yang dapat menjawab soal dengan benar dan lengkap, sedangkan yang lainnya hanya menebak-nebak jawaban saja. Berdasarkan hal tersebut maka dapat disimpulkan bahwa kemampuan berpikir kritis matematis siswa SMP Ar-Rahman Percut masih rendah. Selain itu 
salah satu faktor psikologis yang turut memberikan kontribusi terhadap keberhasilan siswa dalam nengerjakan soal dengan baik adalah kepercayaan diri . Lemahnya kemampuan berpikir kritis siswa berimplikasi pada kepercayaan diri siswa.

Kepercayaan diri sangatlah dibutuhkan oleh siswa agar mampu mengoptimalkan kemampuan yang dimilikinya. Hal ini sejalan dengan pendapat Lauster (Hendriana, 2012), menyatakan bahwa kepercayaan diri merupakan suatu sikap atau perasaan yakin atas kemampuan diri sendiri sehingga orang yang bersangkutan tidak terlalu cemas dalam tindakan-tindakannya, dapat merasa bebas untuk melakukan hal - hal yang disukainya dan bertanggung jawab atas perbuatannya, hangat dan sopan dalam berinteraksi dengan orang lain, dapat menerima dan menghargai orang lain, memiliki dorongan untuk berprestasi serta dapat mengenal kelebihan dan kekurangannya. Oleh karena itu, penting bagi seorang guru untuk memberikan motivasi dalam kegiatan pembelajaran di sekolah.

Kepercayaan diri sangat penting dalam pembelajaran matematika sehingga menjadi aspek yang dapat diteliti oleh TIMSS. Hannula, Maijala, \& Pehkonen (Koriyah dan Harta, 2015) menyebutkan bahwa kepercayaan diri siswa berpengaruh pada pengembangan diri siswa di masa depan serta perkembangan yang mengacu pada keberhasilan dan prestasi siswa. Siswa yang memiliki kepercayaan diri akan berani mencoba presentasi di depan kelas, berani berpendapat, bertanya atau menjawab pertanyaan sehingga mampu menciptakan proses pembelajaran yang aktif seperti yang diharapkan dalam standar proses pendidikan.

Meskipun kepercayaan diri penting pada kenyataannya tingkat kepercayaan diri siswa sekolah menengah secara umum masih rendah. Hal ini berdasarkan hasil penelitian TIMSS (Koriyah \& Harta, 2015) yang menyatakan bahwa siswa memiliki kepercayaan diri yang rendah. Hanya $14 \%$ siswa yang memiliki kepercayaan diri terhadap matematika, sementara itu 45\% siswa kurang memiliki kepercayaan diri, serta $41 \%$ siswa tidak memiliki kepercayaan diri.Rendahnya kemampuan berpikir kritis dan kepercayaan diri siswa ditingkat sekolah tentu berkaitan dengan pembelajaran yang dilakukan di.kelas. Dengan demikian, guru hendaknya memilih pendekatan pembelajaran yang diprediksi mampu meningkatkan kemampuan berpikir kritis dan kepercayaan diri siswa karena sesungguhnya tidak ada satu pun pendekatan yang sesuai diterapkan pada semua siswa (Koriyah dan Harta, 2015). Salah satu pendekatan pembelajaran yang mampu meningkatkan prestasi belajar, kemampuan berpikir kritis dan kepercayaan diri siswa adalah pendekatan open-ended. 
Shimada (Faridah, 2016) mengemukakan bahwa pendekatan open ended adalah pendekatan dalam pembelajaran yang dimulai dengan menyajikan suatu permasalahan kepada siswa, di mana permasalahan memiliki metode atau penyelesaian yang benar lebih dari satu. Hal tersebut serupa dengan pengertian pendekatan open ended yang dikemukakan oleh Sawada (Faridah, 2016) yaitu bahwa pendekatan open ended merupakan suatu pendekatan dalam pembelajaran di mana guru memberikan suatu situasi masalah pada siswa yang solusi atau jawaban masalah tersebut dapat diperoleh dengan berbagai cara.

Analisis di atas mendorong dilakukannya penelitian untuk menjawab permasalahan sebagai berikut.

1. Apakah pencapaian kemampuan berpikir kritis matematis siswa yang pembelajarannya menggunakan pendekatan open ended lebih baik daripada yang menggunakan pembelajaran biasa?

2. Apakah peningkatan kemampuan berpikir kritis matematis siswa yang pembelajarannya menggunakan pendekatan open ended lebih baik daripada yang menggunakan pembelajaran biasa?

3. Apakah terdapat pencapaian kepercayaan diri siswa pada pembelajaran matematika melalui pendekatan open-ended?

\section{METODOLOGI PENELITIAN}

Metode penelitian yang akan digunakan dalam penelitian ini adalah metode Quasi Eksperimen, dengan berbentuk Non Equivalent Control Group Design (Sugiyono, 2011). Pada kuasi eksperimen ini, subjek tidak dikelompokkan secara acak murni tetapi peneliti menerima keadaan subjek seadanya (Ruseffendi, 2010). Populasi seluruh siswa kelas SMP di kota Cimahi. Karena keterbatasan waktu, biaya dan tenaga dipilih sampel sekolah secara acak diperoleh SMP Taruna Mandiri yang memiliki karakteristik yang sama dengan populasi. Karakteristik yang dimaksud adalah kemampuan berpikir kritis dan kepercayaan diri dalam

belajar matematikkemudian dipilih dua kelas secara acak kelas diperoleh kelas VII-B menjadi kelas eksperimen dan kelas VII-C sebagai kelas kontrol. 


\section{HASIL DAN PEMBAHASAN}

\section{Kemampuan Berpikir Kritis Matematik}

Rekapitulasi hasil penelitian kemampuan berpikir kritis siswa antara yang pembelajarannya pendekatan berbasis masalah dengan pendekatan konvensional disajikan dalam tabel berikut:

Tabel 1. Statistik Deskriptif Hasil Tes Kemampuan Berpikir Kritis

\begin{tabular}{cccccccc}
\hline \multirow{2}{*}{ Kemampuan } & \multicolumn{3}{c}{ Kelas Eksperimen } & \multicolumn{3}{c}{ Kelas Kontrol } \\
\cline { 2 - 8 } & & Pretes & Postes & Gain & Pretes & Postes & Gain \\
\hline Berpikir & $\bar{x}$ & 10,97 & 23,91 & 0,31 & 7,06 & 11,46 & 0,10 \\
\cline { 2 - 8 } Kritis & S & 7,18 & 6,48 & 0,19 & 4,73 & 4,37 & 0,10 \\
\hline
\end{tabular}

Keterangan: Skor Maksimum Ideal ( SMI ) tes kemampuan Berpikir Kritis $=50$

Pada tabel 1 rerata gain kelas eksperimen dan gain kelas kontrol yaitu 0,31 dan 0,10 dengan simpangan baku masing-masing 0,19 dan 0,10. artinya secara deskriptif peningkatan kemampuan berpikir kritis kelas eksperimen lebih baik daripada kelas kontrol. Selanjutnya akan di uji kemampuan berpikir kritis yang lebih baik antara kelas eksperimen dan kontrol terlebih dahulu menguji pretes untuk memastikan bahwa kedua kelas tersebut berangkat dari kemampuan yang sama. Berikut hasil pengujian:

Tabel 2. Uji Perbedaan Rerata Data Pretes

\begin{tabular}{lr}
\hline & \multicolumn{1}{c}{ Nilai } \\
\hline Mann-Whitney U & 194,000 \\
Wilcoxon W & 494,000 \\
Z & $-1,767$ \\
Asymp. Sig. (2-tailed) &, 077 \\
\hline
\end{tabular}

Berdasarkan hasil perhitungan Mann-Whitney nilai signifikansinya 0,077. Karena Sig > 0,05 maka $\mathrm{H}_{0}$ diterima. Dengan demikian, dapat disimpulkan bahwa tidak ada perbedaan kelas yang menggunakan kemampuan berpikir kritis matematik siswa yang pembelajarannya menggunakan pendekatan open ended dengan siswa yang pembelajarannya menggunakan pendekatan konvensional dengan taraf signifikansi $5 \%$.

Berdasarkan analisis kemampuan awal siswa skor pretes kemampuan berpikir kritis matematik kedua kelompok menunjukan tidak terdapat perbedaan yang signifikan. Artinya secara signifikan kemampuan berpikir kritis siswa baik kelas eksperimen maupun kelas kontrol memiliki kemampuan awal yang sama. Kemudian kedua kelompok tersebut diberi 
perlakuan yang berbeda yaitu, kelompok eksperimen mendapatkan perlakuan berupa pendekatan open-ended sedangkan kelompok kontrol mendapatkan pembelajarn konvensional.

Pada awal pembelajaran siswa masih belum terbiasa dengan soal berpikir kritis. Hal ini ditunjukan pada saat mengerjakan soal pretes siswa merasa asing dengan bentuk soal berpikir kritis karena siswa terbiasa dengan soal-soal rutin yang prosedur pengerjaanya mencari jawaban dan menghitung sesuai rumus yang ada. Pada tahap ini dapat disimpulkan bahwa kemampuan berpikir kritis siswa belum terlatih karena siswa mengerjakan soal hanya menerapkan prosedur rutin yang ada.

Tahap kemampuan berpikir kritis tidak hanya dapat menerpakan rumus tetapi dapat menganalisis dan mengaplikasikan pengetahuan yang ada yg diterpakan pada masalah non rutin. Hal ini ditegaskan oleh Walker(masitoh \& Prabawanto, 2015) mengatakan bahwa berpikir kritis adalah suatu proses intelektual dalam pembuatan konsep, mengaplikasikan, menganalisis, menyintesis, dan atau mengevaluasi berbagai informasi yang didapat dari hasil observasi, pengalaman, refleksi, di mana hasil proses ini digunakan sebagai dasar saat mengambil tindakan.

Kemampuan berpikir kritis siswa masih sangat kurang diawal pembelajaran hal ini ditunjukan dengan pemberian LKS pertemuan pertama yang membahas materi persegi panjang. Dalam menjawab pertanyaan sangat variatif ada yang tidak sama sekali dapat menjawab, ada yang bisa menjawab tetapi tidak bisa memberikan alasan yang jelas dan ada pula yang dapat menjawab dan memberikan alasan yang tepat, tetapi paling banyak siswa sulit memberikan alasan. Siswa masih sulit mengkomunikasikan apa yang ada dipikirannya untuk di uaraikan dalam bentuk tulisan. Untuk dapat memberikan jawaban yang disertai alasan, siswa harus memiliki keterampilan mengetahui informasi dengan baik sehingga dapat memeberikan alasan yang tepat sesuai informasi yang didapat.

Mengatasi permasalahan tersebut pendekatan open-ended menjadi salahsatu alternatif untuk dapat melatih kemampuan mengetahui informasi dengan baik dan memberikan alasan yang tepat atas jawabannya. Pendekatan open-ended pada tahap awal yaitu menghadapkan siswa pada masalah terbuka. Pada tahap ini secara berkelompok siswa dilatih untuk mengetahui informasi dengan baik, kemudian dapat memeberikan jawaban dengan alasan yang tepat sesuai kemampuannya. 
Mengajarkan berpikir kritis kepada siswa agar siswa menjadi seorang insan intelektual yang apabila menemui masalah tentu dapat berpikir secara kritis terhadap permasalahan kehidupannya sehingga dapat mempertimbangkan dan membuat keputusan yang baik dalam permasalahannya. Hal ini sejalan dengan pendapat Ennis (Sumarmo, 2014) menjelaskan bahwa kemampuan berpikir kritis merupakan kemampuan berpikir reflektif yang penuh dengan pertimbangan dalam pengambilan keputusan mengenai apa yang diyakini dan yang dikerjakan.

Tahap selanjutnya pada pendekatan open-ended yaitu membimbing siswa untuk menemukan pola dan mengkontruksi pengetahuan atau permasalahannya sendiri. Pada tahap ini siswa tidak diberitahukan secara langsung tentang konsep dasar sebuah materi akan tetapi siswa yang harus menemukan pola sendiri dan mengkonstruksi materi pembelajaran dengan bimmbingan seorang guru. Dengan demikian siswa dilatih untuk mengeluarkan ide-idenya untuk menyelesaikan permasalahan yang ada. Ketika siswa harus menemukan pola suatu konsep matematis tentunya siswa harus membandingkan setiap permasalahan dengan sumber atau materi prasyarat dan konsep apa yang tepat untuk menyelesaikan suatu permasalahan. Hal ini sejalan dengan pendapat Bayer (Sumarmo, 2014) yang mengemukakan bahwa berpikir kritis merupakan keterampilan untuk menentukan kredibilitas suatu sumber, membedakan sesuatu yang relevan dan yang tidak relevan dan antara fakta dan penilaian, meng identifikasi dan meng anaslisi asumsi, mengidentifikasi sudut pandang dan mengevaluasi bukti.

Proses ini bermuara pada penemuan konsep baru oleh siswa itu sendiri sehingga siswa dapat mengkonstruksi pengetahuannya sendiri. Akibatnya kemampuan berpikir kritis siswa dapat berkembang dan menjadi lebih meingkat dibandingkan dengan pembelajaran biasa yang hanya menerima pengetahuan secara langsung dari guru tanpa melalui proses berpikir tingkat tinggi.

Tahap selanjutnya pada pendekatan open-ended yaitu membiarkan siswa mencari solusi dan menyelesaikan masalah dengan berbagai penyelesaian. Tahap ini dilakukan setelah siswa menemukan pola ataupun konsep suatu materi selanjutnya siswa mencari solusinya sendiri dengan berbagai penyelesaian.

Pada tahap ini siswa dilatih untuk mandiri dalam menyelesaikan suatu permasalahannya sendiri sehinga siswa mempunyai keperyaan diri dalam belajar matematika. kepercayaan diri siswa muncul karena mereka menyelesaikan permasalahannya sendiri 
bersama teman sekolompoknya sehingga mereka lebih menguasai permasalahan yang mereka selesaikan. Selain itu siswa terlatih untuk berpikir kritis dalam menemukan solusi dari permasalahan dan mencari berbagai cara untuk menyelesaikan permasalahannya. Pola belajar seperti ini diharapkan dapat diterpakan pada mata pelajaran lainnya sehingga prestasi belajar siswa menjadi lebih baik. Hal ini ditegaskan oleh Lunnenburg Nazari (Syarifah \& Sumardi, 2015) bahwa keterampilan berpikir kritis sangat berpengaruh terhadap prestasi belajar peserta didik.

Tahap terakhir pendekatan open-ended yaitu menyajikan hasil temuannya. Pada tahap ini merupakan tahap akhir dalam aktivitas pembelajaran. Dalam menyajikan hasil temuannya siswa harus memahami proses dari awal sampai akhir pembelajaran dan memiliki kemampuan memeriksa kembali sertiap kegiatan yang dilakukan agar dapat menyajikan hasil pembelajaran dengan baik. Kemudian siswa juga harus mempertimbangkan apa yag akan mereka sampaikan terkait hal-hal yang akan menjadi sebuah masalah jika hasil temuannya dipresentasikan. Proses ini akan meningkatkan kemampuan berpikir kritis matematis siswa baik siswa yang menyajikan ataupun yang mejadi audiens. Hal ini juga dipertegas oleh Ennis (Sumarmo, 2014) yang menjelaskan bahwa kemampuan berpikir kritis merupakan kemampuan berpikir reflektif yang penuh dengan pertimbangan dalam pengambilan keputusan mengenai apa yang diyakini dan yang dikerjakan.

Karena kedua sampel berangkat dari kemampuan yang sama, dapat di bandingkan kemampuan pemahaman matematika antara kelas eksperimen dan kelas kontrol. Adapun pengujiannya sebagai berikut:

\begin{tabular}{|c|c|c|c|}
\hline $\begin{array}{l}\text { abel 3. U } \\
\text { Kelas }\end{array}$ & $\begin{array}{r}\text { erbec } \\
\bar{x}\end{array}$ & $\begin{array}{c}\text { era } \\
\text { s }\end{array}$ & $\begin{array}{l}\text { Poste } \\
\text { Sig }\end{array}$ \\
\hline Eksperimen & 23,91 & 6,48 & 0,000 \\
\hline Kontrol & 11,46 & 4,37 & 0,000 \\
\hline
\end{tabular}

Terlihat pada Tabel 5.5 didapat Sig sebesar 0,000. Menurut Uyanto (2009: 145) karena kita akan menguji 1 arah (1-tailed) maka signifikasi untuk 2-tailed harus di bagi dua. Nilai signifikansinya adalah $\frac{0,000}{2}=0,000$. Karena sig $<0,05$ dengan kata lain $\mathrm{H}_{0}$ ditolak artinya Pencapaian kemampuan berpikir kritis matematik siswa yang pembelajarannya menggunakan pendekatan pembelajaran open ended lebih baik daripada siswa yang pembelajarannya menggunakan pendekatan konvensionalpada taraf signifikansi 5\%. Selanjutnya, untuk 
mengetahui peningkatan kemampuan berpikir kritis siswa dilakukan pengujian gain ternormalisasi, seperti yang disajikan dalam tabel berikut:

\begin{tabular}{|c|c|}
\hline & Gain \\
\hline Mann-Whitney U & 92.000 \\
\hline Wilcoxon W & 392.000 \\
\hline $\mathrm{Z}$ & -3.929 \\
\hline Asymp. Sig. (2-tailed) & .000 \\
\hline
\end{tabular}

Pada Tabel 4 diperoleh Sig sebesar 0,000. Menurut Uyanto(2009: 145) karena kita akan menguji 1 arah (1-tailed) maka signifikasi untuk 2-tailed harus di bagi dua. Nilai

signifikansinya adalah $\frac{0,000}{2}=0,000$. Karena sig $<0,05$ dengan kata lain $\mathrm{H}_{0}$ ditolak artinya Peningkatan kemampuan berpikir kritis matematik siswa yang pembelajarannya menggunakan pendekatan pembelajaran open ended lebih baik daripada siswa yang pembelajarannya menggunakan pendekatan konvensional pada taraf signifikansi $5 \%$.

Kesimpulannya, pencapaian dan peningkatan kemampuan beripikir kritis matematik siswa menunjukan bahwa siswa yang pembelajarannya menggunakan pendekatan open-ended mempunyai kemampuan berpikir kritis matematik yang lebih baik dibandingkan dengan siswa yang pembelajarannya menggunakan pendekatan konvensional pada taraf signifinikan $\propto=$ 5\%. Oleh karena itu pendekatan open-ended direkomendasikan untuk digunakan dalam pembelajaran pada topik-topik tertentu karena pendekatan ini memberikan ruang untuk siswa berpikir kritis mencari solusi permasalahan sehingga mampu mengembangkan dan meningkatkan kemampuan berpikir kritis matematik siswa.

\section{Kepercayaan Diri}

Tingkat kepercayaan diri siswa secara umum masih rendah. Tentunya banyak faktor yang menyebabkan tingkat kepercayaan diri siswa rendah. Salah satu faktor utamanya adalah siswa yang belum memahami materi pada pembelajaran matematika. ketika seorang siswa tidak faham akan suatu materi siswa cenderung takut dalam belajar sehingga tingkat kepercayaan diri siswa rendah.

Penguasaan konsep awal atau penguasaan materi prasyarat sangatlah penting ketika pembelajaran berlangsung. Kebanyakan siswa motivasinya kurang dalam belajar matematika 
adalah karena penguasaan materi sebelumnya atau materi prasyaratnya tidak dikuasai dengan baik. Oleh karena itu, pembelajaran open-ended menjadi salah satu alternatif untuk meningkatakan keperayaan diri siswa dalam belajar matematika.

Pada pembelajaran open-ended terlebih dahulu siswa dikelompokan yang terdiri atas 45 orang dalam satu kelompok dengan tujuan suapaya siswa tidak takut dalam belajar karena proses pembelajarannya dilakukan secara bersama-sama. Selain itu, siswa dapat berdiskusi secara langsung dengan teman sekelompoknya untuk saling berbagi tentang materi yang sedang berlangsung. Melalui model berkelompok siswa menjadi lebih percaya diri karena ruang lingkupnya lebih sedikit, namun perlu diketahui bahwa pembelajaran kelompok juga mempunyai kelemahan yaitu ada sekolompok siswa yang senang berdiskusi diluar topik yang dibicarakan. Disinilah peran guru yang harus mempunyai kemampuan pedagogik seorang guru dalam mengelola kelas.

Siswa yang kurang percaya diri dalam belajar matematik pada dasarnya karena siswa kurang aktif dalam pembelajaran, malu bertanya pada guru dan kurang mempunyai kesempatan untuk mencoba. dengan pembelajaran pendekatan open-ended siswa menjadi lebih aktif karena pendekatan open-ended merupakan pembelajaran lebih berpusat kepada siswa, artinya siswa lebih aktif dalam pembelajaran dan tugas guru sebagai fasilitator dalam kegiatan belajar mengajar. Hal ini dilakukan supaya siswa dapat meningkatkan kepercayaan dirinya dalam belajar matematika. Ketika rasa percaya diri muncul diharapkan siswa lebih bersemangat dalam belajar matematika sehingga siswa dapat menguasai materi pembelajaran dengan baik. Hal ini sejalan dengan pendapat Hendriana (2012) yang mengemukakan bahwa kepercayaan diri akan memperkuat motivasi mencapai keberhasilan, karena semakin tinggi kepercayaan terhadap kemampuan diri sendiri, semakin kuat pula semangat untuk menyelesaikan pekerjaannya.

Pada tahap awal pendekatan open-ended yaitu menghadapkan siswa pada masalah terbuka. Pada tahap ini siswa menyelesaikan permasalahannya sesuai dengan pengalaman dan pengetahuannya sendiri artinya tahap ini melatih siswa untuk mempunyai keyakinan kemampuan diri. Keyakinan menurrut Scoenfeld (Hapsari, 2011) adalah pemahaman dan perasaaan individu yang membentuk cara bahwa konsep individu dan terlibat dalam perilaku matematika. Tahap ini merupakan langkah yang sangat berat di awal pembelajaran karena 
siswa belum terbiasa dengan pembelajaran pendekatan open-ended dan guru harus memotivasi untuk belajar mandiri menyelesaikan permasalahannya.

Tahap berikutnya pada pendekatan open-ended yaitu membimbing siswa untuk menemukan pola dan mengkontruksi pengetahuan atau permasalahannya sendiri. Tahap ini peran guru dalam membimbing siswa sangatlah penting karena tahap ini berfungsi menjaga stabilitas keyakinan siswa dalam belajar matematika. Kurangnya dalam membimbing dapat menurunkan motivasi dan keyakinan belajar siswa. Oleh karena itu, guru harus membuat siswa terlibat dalam pembelajaran dan memahami setiap perintah yang ada pada LKS pendekatan open-ended.

Setelah siswa dibimbing untuk terlibat dalam menemukan pola dan mengkontruksi pengetahuannya, tahap selanjutnya yaitu membiarkan siswa mencari solusi dan menyelesaikan masalah dengan berbagai penyelesaian. Pada tahap ini menjadi alat ukur guru untuk melihat seberapa besar tingkat kepercayaan diri siswa karena siswa harus mencari solusi permasalahannya dengan kemampuannya sendiri bersama teman sekelompoknya.

Ketika seorang siswa sudah mampu percaya diri dalam belajarnya diharapakan akan percaya diri dalam mengatasi masalah kehidupannya. Hal ini ditegaskan Rakmat (Hendriana, 2012) yang mengatakan bahwa kepercayaan diri atau keyakinan diri diartikan sebagai suatu kepercayaan terhadap diri sendiri yang dimiliki setiap individu dalam kehidupannya, serta bagaimana individu tersebut memandang dirinya secara utuh dengan mengacu pada konsep diri.

Tahap terakhir pada pendekatan open-ended yaitu menyajikan hasil temuannya. Pada tahap ini siswa harus bertanggung jawab dengan hasil temuannya, optimis dalam menyampaikan pendapatnya, objektif saat melihat pendapat yang lain dan berpikir rasional dalam setiap memahami permasalahan yang ada. Tahap-demi tahap pendekatan open-ended sangat mendukung siswa untuk lebih percaya diri dalam belajar matematika dibandingkan dengan pendekatan konvensional yang kurang memberikan ruang untuk setiap siswa lebih aktif menyelesaikan permasalahannya Pembelajaran konvensional hanya berusat pada guru dan siswa yang terlibat aktif kebanyakan siswa yang memiliki kemampuannya tinggi sedangkan siswa yang keampuannya rendah cenderung fasif dalam pembelajaran.

Selain itu berasarkan uji statistik analisis pencapaian kepercayaan diri siswa dalam belajar matematik menunjukan bahwa siswa yang pembelajarannya menggunakan pendekatan 
Jurnal PRISMA Universitas Suryakancana

open-ended mempunyai tingkat kepercayaan diri yang lebih baik dibandingkan dengan siswa yang pembelajarannya menggunakan pendekatan konvensional pada taraf signifinikan $\propto=$ 5\%. Oleh karena itu, pendekatan open-ended direkomendasikan untuk digunakan dalam pembelajaran pada topik-topik tertentu karena pendekatan ini mampu mengembangkan dan meningkatkan kepercayaan diri siswa dalam belajar matematika.

\section{KESIMPULAN}

Berdasarkan analisis data dan pembahasan yang dikemukakan pada bab sebelumnya, dapat disimpulkan bahwa pencapaian kemampuan berpikir kritis matematik siswa yang pembelajarannya menggunakan pendekatan open-ended lebih baik daripada yang menggunakan pendekatan konvensional, Peningkatan kemampuan berpikir kritis matematik siswa yang pembelajarannya menggunakan pendekatan open-ended lebih baik daripada yang menggunakan pendekatan konvensional, dan kepercayaan diri dalam belajar matematik siswa yang pembelajarannya menggunakan pendekatan berbasis masalah lebih baik daripada yang menggunakan pendekatan konvensional.

\section{REFERENSI}

Faridah, N., Atun, I. Aeni, A. N. (2016). Pendekatan Open-Ended untuk Meningkatkan Kemampuan Berpikir Kreatif Matematis dan Kepercayaan Diri Siswa. Jurnal Pena Ilmiah, 1(1), pp.1061-1070). Retrieved from http://ejournal.upi.edu/index.php/penailmiah/index

Fauziyah (2016). “ Kesulitan Siswa Belajar Matematika SMP”. [Studi Pemula]. Cimahi : (tidak diterbitkan).

Hapsari, M. J. (2011). Upaya Meningkatkan Self-Confidence Siswa Dalam Pembelajaran Matematika Melalui Model Inkuiri Terbimbing (Matematika dan Pendidikan Karakter dalam Pembelajaran). Seminar Nasional Matematika dan Pendidikan Matematika, pp. 337-345 Jurusan Pendidikan Matematika FMIPA UNY .

Hendriana, H. (2012). Pembelajaran Matematika Humanis dengan Metaphorical Thinking untuk Meningkatkan Kepercayaan Diri Siswa. Infinity Journal. 1(1), pp.90-103. DOI: http://dx.doi.org/10.22460/infinity.v1i1.9

Jumaisyaroh,T. dkk.(2014). Peningkatan Kemampuan Berpikir Kritis Matematis dan Kemandirian Belajar Siswa SMP melalui Pembelajaran Berbasis Masalah. Jurnal Kreano: vol 5 (2). pp 157-169.

Koriyah, V \& Harta, I. (2015). Pengaruh Open-Ended terhadap Prestasi Belajar, Berpikir Kritis dan Kepercayaan Diri Siswa SMP. PYTHAGORAS: Jurnal Pendidikan Matematika. 10 (1), 98. 
Masitoh, I. \& Prabawanto, A. (2015). Peningkatan Pemahaman Konsep Matematika dan Kemampuan Berpikir Kritis Matematis Siswa Kelas V Sekolah Dasar melalui Pembelajaran Eksploratif. EduHumaniora: Jurnal Pendidikan Dasar 7(2), pp. 186-197. DOI: http://dx.doi.org/10.17509/eh.v7i2

Ruseffendi, E.T. (2010). Statistik Dasar untuk Penelitian Pendidikan. Semarang: IKIP Semarang Press.

Sugiyono. (2011). Metode Penelitian Kuantitatif, Kualitatif, dan $R \&$ D. Bandung: Alfabeta.

Sumarmo, U. (2014). Berpikir dan Disposisi Matematika serta Pembelajarannya. Bandung : Jurusan Pendidikan Matematika FPMIPA-UPI.

Syahbana, A.(2012). Peningkatan Kemampuan Berpikir Kritis Matematis Siswa SMP Melalui Pendekatan Contextual Teaching and Learnin. Jurnal Edumatica Volume 02 pp 45-57.

Syarifah \& Sumardi, Y. (2015). Pengembangan Model Pembelajaran Malcolm's Modeling untuk Meningkatkan Keterampilan Berpikir Kritis dan Motivasi Belajar Siswa. Jurnal Inovasi Pendidikan IPA. 1(2), pp. 237-247. Retrieved from : http://journal.uny.ac.id/index.php/jipi/index

Uyanto, S. (2009). Pedoman Analisis Data dengan SPSS. Bandung: Graha Ilmu

Yanti, S. (2015). Pengaruh Konsep Diri dan Kemampuan Komunikasi Interpersonal terhadap Kemampuan Berpikir Kritis Matematika. Jurnal Ilmiah Pendidikan MIPA, 5(3), pp. 202-209. Retrieved from : $\underline{\text { http://journal.lppmunindra.ac.id/index.php/Formatif/index }}$ 